\title{
The Use of Matrix Heat Pipe as Photovoltaic Cooler
}

\author{
Rahmat Subarkah ${ }^{1}$, Tatun Hayatun Nufus ${ }^{1}$, Rahmat A Setiawan ${ }^{1}$, Achmad Subakri ${ }^{1}$, \\ Wisnu Tri Nur Kahfi ${ }^{1}$, and Try Laksono Prasetyo ${ }^{1}$
}

\begin{abstract}
The high surface temperature can decrease the efficiency of solar cells. This research aim is to decrease the temperature of the solar cell using the matrix heat pipe as a heat conductor. The study began by constructing a matrix of heat pipes. $1 / 4$ inch diameter copper tubing $(6.3 \mathrm{~mm})$ pressed until it reaches a thickness of $4.2 \mathrm{~mm}$. Heat pipe using 10 mesh wire screen and water as the working fluid as about $20 \%$ of the volume of the pipe. Twenty-five heat pipes arranged matrix configuration. The pipes were vacuumed to pressure 0.0799 bar. Flat heat pipe were placed below the surface of the solar cell. Phase change liquid-gas of work fluid on the heat pipe occurs at saturated temperature of $42^{\circ} \mathrm{C}$. This heat pipe reduces surface temperature of solar cell as $8^{\circ} \mathrm{C}$ and increase efficiency of solar cell as $1.6 \%$.
\end{abstract}

Keywords_- Matrix Heat Pipe, Solar Cell.

\section{INTRODUCTION}

$\mathrm{S}^{\mathrm{o}}$ olar energy is the energy gained by converting solar energy into other forms of resources. In the utilization of solar energy, has been developed a technology that can convert solar energy into electrical energy. This technology is known as a solar cell or photovoltaic [1].

A solar cell is an active element that converts sunlight into electrical energy [2]. At present, almost all solar cells have an efficiency of about $24 \%$, one of the shortcomings of solar cells is by increasing the temperature will decrease efficiency [3].

Increase in temperature generated by solar cells solar heat greatly affects the performance of solar cells. To achieve optimal operation capability then the heat on solar cells must be reduced to the maximum, it is necessary to cool the solar cell. Various methods have been developed to improve the efficiency of solar cells. One of them is by using heat pipe matrix type.

\section{A. Solar Energy}

The sun is the primary energy resource that emits enormous energy to the earth's surface. The sun is the basis of life on Earth, all energy use, directly or indirectly requires sunlight. Each year the sun emits 20,000 times the energy required from all over the world [2].

Indonesia is located on the the equator has the potential for significant solar energy throughout the year. This allows the utilization of solar energy into energy that can be relied to human life in the future.

\section{B. Solar Cell}

Solar cells are an active element that converts solar radiation into electrical energy [2]. Solar cells are made of small silicon pieces [4] coated with special chemicals to form the basis of solar cells. Solar cells generally have a thickness of 0.3 [mm] [2], which is made from slices of semiconductor materials with positive and negative poles.

${ }^{1}$ Rahmat Subarkah, Tatun Hayatun Nufus, Rahmat A Setiawan, Achmad Subakri, Wisnu Tri Nur Kahfi, and Try Laksono Prasetyo are with Departement of Mechanical Engineering, Politeknik Negeri Jakarta, Jakarta, Indonesia. E-mail: rahmat.subarkah@mesin.pnj.ac.id.
It is known that the difference of efficiency between cooled solar cells with not cooled solar cells by $0.66 \%$ [5]

\section{Heat Pipe}

Heat pipe is a heat conductor technology using a certain sized pipe containing a special fluid as a conductor of heat from the hot end to the other end as a cooler [6]. The pipes are usually made of aluminum, copper or nickel plated copper [7, 8]. Heat pipe is described as an application implemented in the refrigeration system. Heat pipe is applied to solve the problems on heat absorption or in other words, the evaporation of liquid fluid at a certain temperature where the heat transfer occurs without the use of additional energy in the working fluid circulation.

\section{Heat Pipe Mechanism}

Masaru Ommi [9] said that there are some standard components that affect the performance of a heat pipe, which are heat pipe working fluid and the capillarity structure of the heat pipe.

Mechanism of heat conduction in the pipe heat conduction occurs through three regionthat, evaporator, adiabatic and condenser area. Vaporized working fluid in the evaporator through the adiabatic region until it reaches toward the condenser region [9]. Heat released in the condenser so that the vapor condenses and working fluid flows into the evaporator due to the capillarity of wick. Although heat pipes could dissipate heat continuously to the condenser, this process will continue as long as there is sufficient capillary pressure to return the fluids to the evaporator [10].

\section{METHOD}

Matrix type heat pipe configured in parallel relationship between the pipes. Heat pipe is created using $1 / 4$ inch diameter copper pipe with a length of $700 \mathrm{~mm}$. The pipe was flattened to the thickness to $4.9 \mathrm{~mm}$. Number of heat pipes used as many as 25 pieces with the distance between the axis by $15 \mathrm{~mm}$. Wick screen mesh used is stainless steel 10 mesh screen size. Working fluid is filled as much as $20 \%$ of the total volume of the heat pipe. The heat pipe is vacuumed at a pressure of 0.0799 bar. A technique of data collection is carried out as follows Figure 3. 
In this study the collected data are the intensity of solar radiation, electrical current and voltage generated by the solar cell, the water temperature in and out of heat exchanger, and the temperature of the upper and lower surface of the solar cell, the cooling water flow rate.

\section{A. Data Collection Procedures}

Stages of data collection is set the cooling water flow rate by using a measuring cup and stopwatch for 200, 250, 300, 350 and $400 \mathrm{ml} / \mathrm{min}$, measure the current and voltage generated solar cells, measuring the surface temperature of the solar cells every 10 minutes and perform testing at 08:00 to 15:00.

\section{B. Filling Ratio Determination of Working Fluid}

One of the very important process in making the heat pipe is to determine the ratio of the working fluid to the total volume of the heat pipe. The amount of filling ratio of the working fluid can affect the propagation of heat because of the more fluid it will require more heat to vaporize the fluid.

However, if a little filling ratio can cause fluid in the evaporator vapor is discharged while in the condenser has not been back to the evaporator. As a result, the working fluid in the evaporator runs out. In this condition the heat pipe temperature increases and can not dissipate heat. This is known as over-heat condition.

Below is a table of the results of testing the working fluid filling ratio in Table 1 . Based on the experiment shows that the working fluid volume by 74 [ml] or $20 \%$ of the total volume of the heat pipe will get to work effectively because of heat transferred from the evaporator to the condenser quickly, which is 9 seconds and delivered heat is spread uniformly throughout the condenser.

If conditions exceed the limits of the wick heat pipes can no longer return the liquid to the evaporator, the evaporator reaches the driest point that causes overheating in the evaporator heat pipe.

Filling ratio of working fluid used is $20 \%$, this number is considered ideal to get a heat pipe works effectively because it has a rapid velocity of heat transfer and can avoid the the over-heat.

\section{RESULT AND DISCUSSION}

The solar energy absorbed by the solar cells is then converted into electrical energy, but not all the absorbed energy is converted into electrical energy but also become hot. The heat that arises on the surface of the solar cell is then forwarded to the copper plate are below.

Heat is absorbed by the copper plate and then forwarded to the evaporator section of heat pipe, heat is absorbed and then propagate to condenser section of heat pipe inside the heat exchanger.

Heat transfer by convection occurs on the fins of the heat pipe condenser inside heat exchanger resulting in cooling water temperature increases.

From Figure 4, 5, 6, 7, and 8 can be seen the difference in temperature between the upper surface of the cooling solar cell and solar cell without cooling. Based on the test results, there is a considerable temperature difference when the surface temperature of the solar cells reaches $50{ }^{\circ} \mathrm{C}$. At temperatures below $50{ }^{\circ} \mathrm{C}$ temperature difference between the surface of the cooling solar cell and solar cell without cooling to zero, this means that very little heat is absorbed and delivered by the heat pipe.

Heat pipe with water working fluid at a pressure of 0.0799 bar vacuumed. At this pressure, the saturation temperature of water is $42{ }^{\circ} \mathrm{C}$. At temperatures under the saturation temperature, the absorbed heat is used to increase the temperature of the working fluid. At the saturation temperature, the heat absorbed in the evaporator is used for fluid phase change from liquid to vapor. At this point the steam fast propagates toward the condenser carrying heat.

Based on experimental, at a temperature of $30-50{ }^{\circ} \mathrm{C}$ heat absorbed by the heat pipe is used to increase the temperature of the fluid and can not dissipate heat from the evaporator to the condenser and the temperature of the surface of solar cells have not experienced of cooling.

\section{A. Average temperature of cooling water inlet and oulet}

From the figure above shows the difference in the average temperature of the outlet water, the chart above shows that the variation of water discharge does not significantly affect the temperature of the outlet water. There are several factors that affect the temperature of the outlet water, one of which is the intensity of solar radiation that is always changing. The largest average outlet water temperature is shown on $250 \mathrm{ml} / \mathrm{min}$ which has the greatest average intensity of solar radiation. This shows that the biggest factor affecting the temperature of the outlet water is the intensity of solar radiation.

From the figure above shows the difference between inlet and outlet water temperature, the greater the flow of water so the less the difference in inlet and outlet water temperature. The largest average temperature difference of inlet and outlet water obtained in the testing of 250 $\mathrm{ml} / \mathrm{min}$ at $5.7^{\circ} \mathrm{C}$ and the smallest average temperature difference between inlet and outlet water obtained in the testing of $400 \mathrm{ml} / \mathrm{min}$ at $2.4{ }^{\circ} \mathrm{C}$.

\section{B. Average surface temperature of the solar cell}

From the figure above it can be seen comparing the surface temperature of solar cells on some variation of water flow. The greater the cooling water flow the greater difference in temperature between the surfaces of the cooled solar cell and solar cells without cooling. This means that a large flow of water gives a rapid drop in temperature in the heat pipe so that the surface of the solar cell faster drops.

The greatest average temperature difference between the surface-cooled solar cells and solar cells without cooling obtained on testing of $400 \mathrm{ml} / \mathrm{min}$ of $7.4{ }^{\circ} \mathrm{C}$ while the smallest obtained in the testing of $200 \mathrm{ml} / \mathrm{min}$ of $1.6^{\circ} \mathrm{C}$.

\section{Average power output of solar cells}

In the figure above shows that the greater water flow then the power output tends to be smaller, this is because the light intensity is constantly changing every test.

The greater in water flow then the difference of power output of solar cells and solar cell without cooling will be greater. The greatest difference of power output of solar cells and solar cells without cooling obtained at 400 $\mathrm{ml} / \mathrm{min}$ of 0.83 watts while the smallest obtained at 200 $\mathrm{ml} / \mathrm{min}$ of 0.01 watts. 


\section{Total output power of solar cell}

From the picture above shows the total power difference-cooled solar cells and solar cells without cooling. Solar cells with cooling have two advantages, which is decreasing the temperature of the solar cells and producing hot water. Two of these advantages result in greater total power of the solar cell without cooling only generate electrical power.

From the above chart shows the greater flow of water, the greater the difference in the total power. The total power is also influenced by the intensity of sunlight so that the chart above is not linear. The greatest difference in average total power cooled heat pipe solar cells and solar cells without cooling obtained in the testing of 250 $\mathrm{ml} / \mathrm{min}$ that is 99.4 watts and while the smallest obtained in the testing of $200 \mathrm{ml} / \mathrm{min}$ that is 78.39 watts.

\section{E. The total efficiency of solar cell}

From the Figure it can be seen the difference in total efficiency solar cells with heat pipe cooling and solar cells without cooling. Heat pipe cooled solar cells have efficiencies greater than solar cells without cooling. Solar Cells cooled have a greater total efficiency because it has a cooling system that can reduce the surface temperature of the solar cell and produce hot water as thermal energy. The total efficiency is the sum of the value of the efficiency of the solar cell to generate electrical energy and produces hot water as thermal energy.

From the above chart shows the difference between the total efficiency of the heat pipe cooled solar cells and solar cells without cooling. The greater of water flow then greater the difference in total efficiency. The largest difference in total efficiency of cooled heat pipe solar cells and solar cells without cooling obtained on testing $400 \mathrm{ml} / \mathrm{min}$ at $38.12 \%$, while the smallest obtained in the testing of $200 \mathrm{ml} / \mathrm{min}$ at $28.72 \%$.

\section{F. Average efficiency of solar cell}

Figure shows the differences in the efficiency of solar cells and solar cells with cooling without cooling. Heat pipe cooled solar cells have better efficiency than solar cells without cooling. Cooled solar cells have efficiencies greater because of the high temperatures on the surface of the solar cell is transferred through heat pipes and forwarded to the cooling water. Theoretically, graph above linear, the greater the flow of water, the greater the efficiency. The cause of the graph above is not linear fluctuating light intensity.

From the graph above shows the difference in the efficiency of solar cells and solar cell without cooling. The greater the flow of water, the greater the difference in efficiency. The greatest difference in average efficiency solar cells and solar cell without cooling is in most testing $400 \mathrm{ml} / \mathrm{min}$ of $0.15 \%$, while the smallest obtained in the testing of $200 \mathrm{ml} / \mathrm{min}$ by $0.41 \%$.

\section{SUMMARY}

From this study it can be concluded that the solar cell equipment cooled heat pipe matrix type can work well to increase the efficiency of solar cells and produce warm water. Based on the data obtained from testing the water temperature reached $44.3^{\circ} \mathrm{C}$ at the maximum debit of $250 \mathrm{ml} / \mathrm{min}$. Debit $300 \mathrm{ml} / \mathrm{min}$ maximum temperature reached $40.7{ }^{\circ} \mathrm{C}$ while for discharge $350 \mathrm{ml} / \mathrm{min}$ maximum temperature of $37.9^{\circ} \mathrm{C}$ and for discharge 400 $\mathrm{ml} / \mathrm{min}$ maximum temperature of $40.9{ }^{\circ} \mathrm{C}$. Based on data from the test can be concluded that the largest electric power generated at solar cells cooled $47.58 \mathrm{~W}$ on testing with debit of $200 \mathrm{ml} / \mathrm{min}$ at $09.50 \mathrm{pm}$, while the ordinary solar cells only reached $46.94 \mathrm{~W}$. After testing is done it can be seen that the maximum water temperature reaches $44.3^{\circ} \mathrm{C}$ on testing with debit $250 \mathrm{ml}$ / $\mathrm{min}$ at $13: 10 \mathrm{pm}$. While the maximum efficiency of a coolled solar cell using can reach $26.4 \%$ on the test with a debit of $250 \mathrm{ml} / \mathrm{min}$ at $08.30 \mathrm{pm}$. The maximum hot water temperature of $44.3{ }^{\circ} \mathrm{C}$ sebsar the energy absorption efficiency at $80.1 \%$, it can be concluded that the matrix-type heat pipe can transfer heat from the dam to absorb the solar cell to the cooling water very well. The hot water produced is also able to meet the domestic hot water needs.

\section{REFERENCES}

[1]. Naville, Richacard C. 1995. Solar Energy Conversion. Elsevier. USA

[2]. Sigalingging, Drs. Karmon. Pembangkit Listrik Tenaga Surya.Tarsito Bandung. 1994.

[3]. Amin Rahrjo, Herlina, dan Husni Safruddin, 2008. Optimalisasi Pemanfaatan Sel Surya Pada Bangunan Komersial Secara Terintegerasi Sebagai Bangunan Hemat Energi. Seminar Nasional Sains dan Teknologi-II 2008 Universitas Lampung, 1718 November 2008. ISBN : 978-979-1165-74-7. Hal 56-65.

[4]. Zekai.2008. Solar Energy Fundamentals And Modeling Techniques. Springer. Istanbul.

[5]. Swapril Dubey, G S. Sandhu, GN. Tiwari.’'Analytical expression for electrical efficiency of PV/Hybrid air Collector". Center Of Technology Delhi, Hauz Khas. New Delhi 110016 India, 2009.

[6]. J.A Easmant, S.U.S Choi, S. Li, Anomalously Increased Effective Thermal Conductivities of Ethylene Glycol-Based Nanofluids Containing Copper Nanoparticles, Applied Physics Letters, Volume 78, No. 6, pp.718, 2001.

[7]. Leonard L, Vasiliev., Review Heat Pipes in Modern Heat Exchangers. Applied Thermal Engineering 25, pp.1-19, 2005

[8]. Harris, James R., Modeling, Designing, Fabricating and Testing of Channel Panel Flat Plate Heat Pipe. Utah State University, pp.1-6, 2008.

[9]. Ommi, Masaru \& Tushiro Fukumoto., State-of-the-art Technologies of Micro Heat Pipe Heat-Sinks for Notebook PCs Thermal Products Dept., Electronic Components Division and Components and Mounting Technology Development, 2000.

[10]. Grover, G.M., Evaporation-Condensation Heat Transfer Device, US Patent No. 3229759, Appl. 2 Desember, 1963, Published 18 January, 1966.

[11]. Wits, W., R. Legtenberg, J.H Mannak., Selecting Capilary Structures for Heat Pipe in Multilayer Printed Circuit Boards, European Thermal-Science, The Netherlands, 2008. 


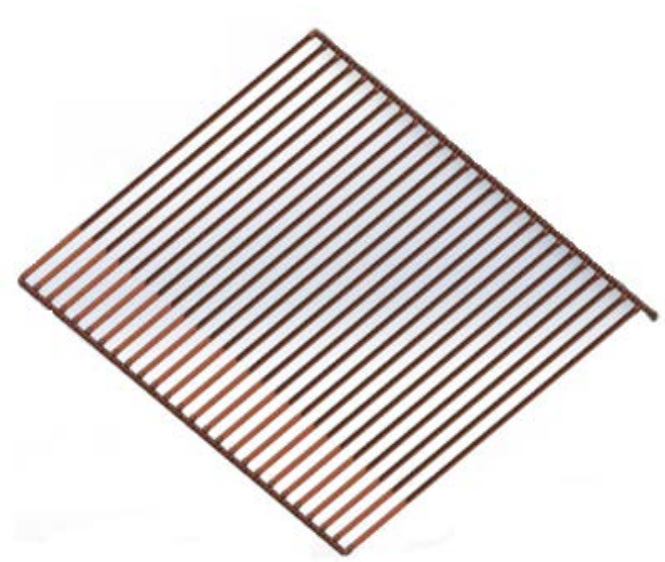

Figure 1. Matrix Typed Heat Pipe

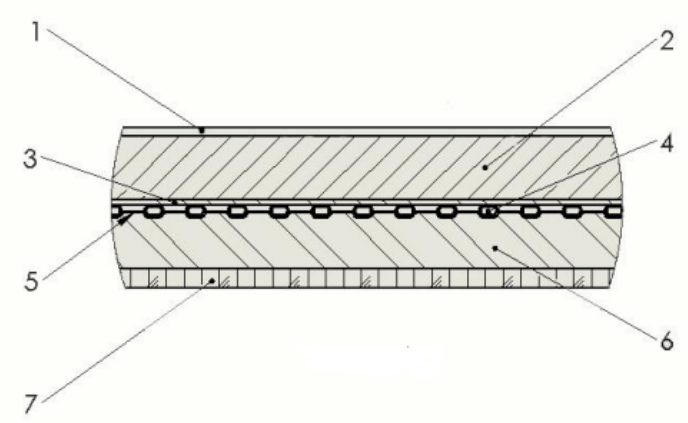

Figure 2. Cross Section Matrix Typed Heat Pipe 1 = Copper Plate 2 = Solar Cell. 3 = Alumunium Foil. 4 = Matrix Typed Heat Pipe $5=$ Isolator $6=$ wooden board

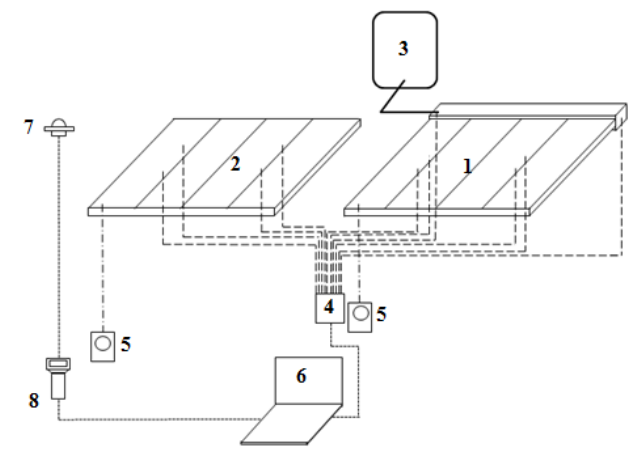

Figure 3. Scheme of data collection techniques.

1: cooled Solar cells; 2: Solar cells without colling; 3: water tank. 4: temperature datalogger. 5: Multimeter. 6: PC;

7: Pyranometer. 8: Datalogger Pyranometer

............ suhu permukaan sel surya berpendingin pipa kalor tipe matriks

- - - - suhu permukaan sel surya tanpa pendingin

Intensitas Cahaya Matahari

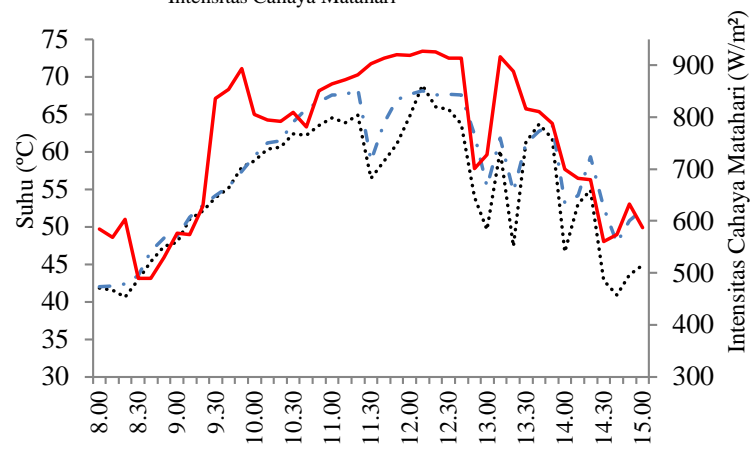

Waktu

Figure 4. Surface temperature of the solar cells on debit of $200 \mathrm{ml} / \mathrm{min}$

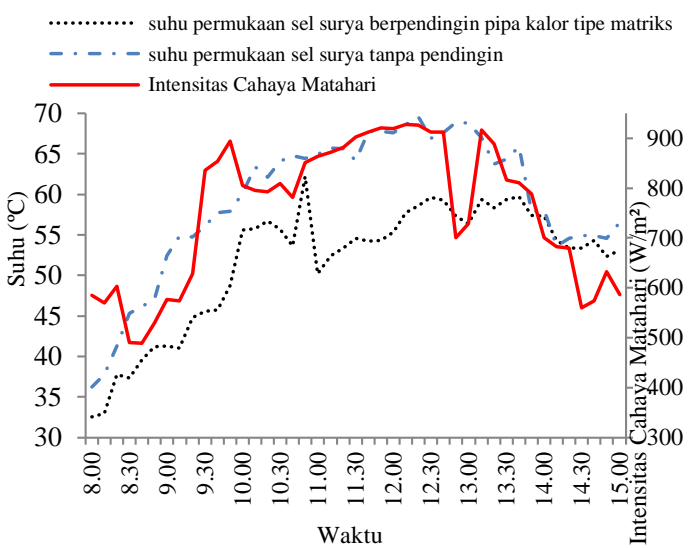

Figure 5. Surface temperature of the solar cells on debit of 250 $\mathrm{ml} / \mathrm{menit}$

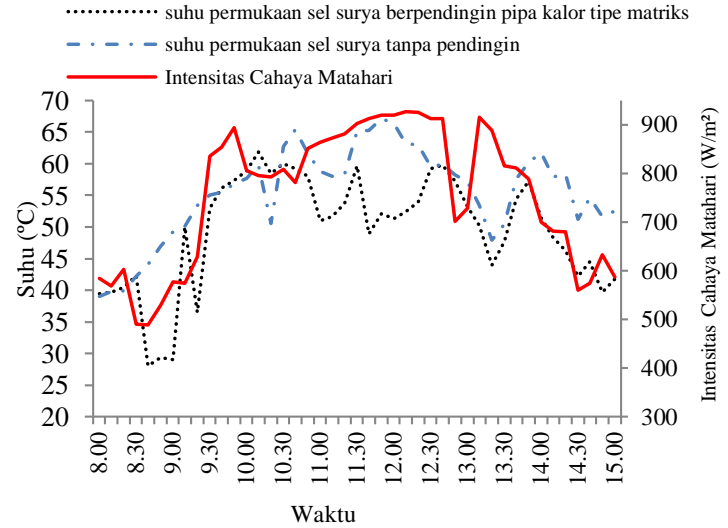

Figure 6. Surface temperature of the solar cells on debit of 300 $\mathrm{ml} / \mathrm{menit}$

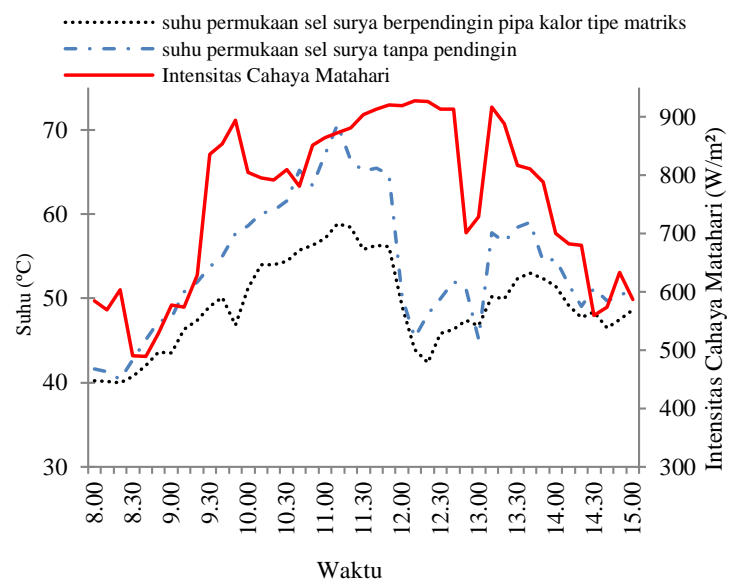

Figure 7. Surface temperature of the solar cells on debit of 350 $\mathrm{ml} / \mathrm{menit}$

............ suhu permukaan sel surya berpendingin pipa kalor tipe matriks -. - - suhu permukaan sel surya tanpa pendingin

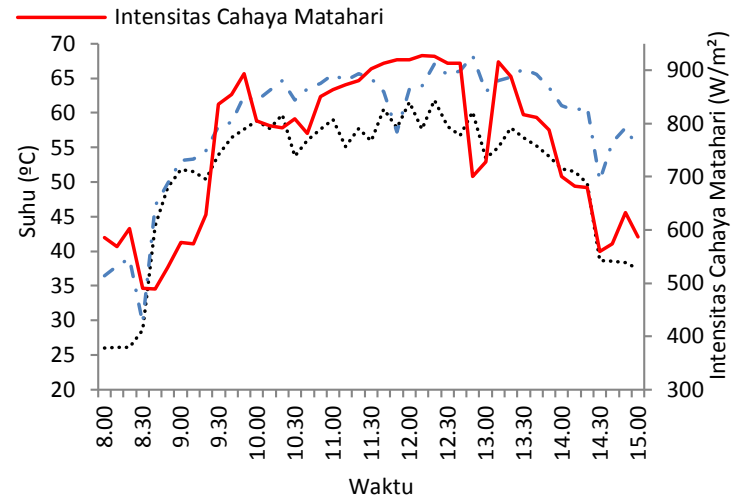

Figure 8. Surface temperature of the solar cells on debit of 400 $\mathrm{ml} / \mathrm{menit}$ 


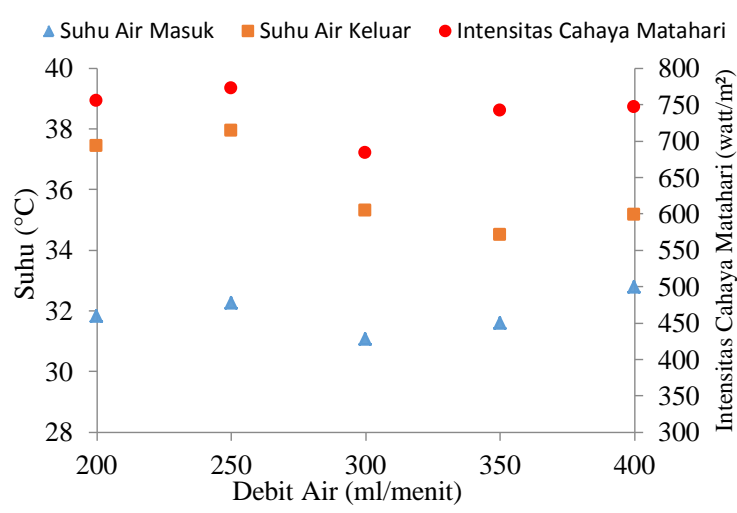

Figure 9. Average temperature of cooling water inlet and outlet

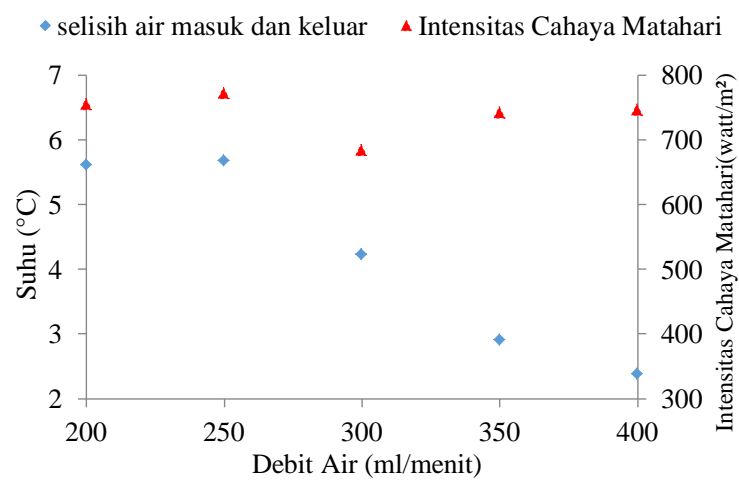

Figure 10. the average temperature difference between inlet and outlet water

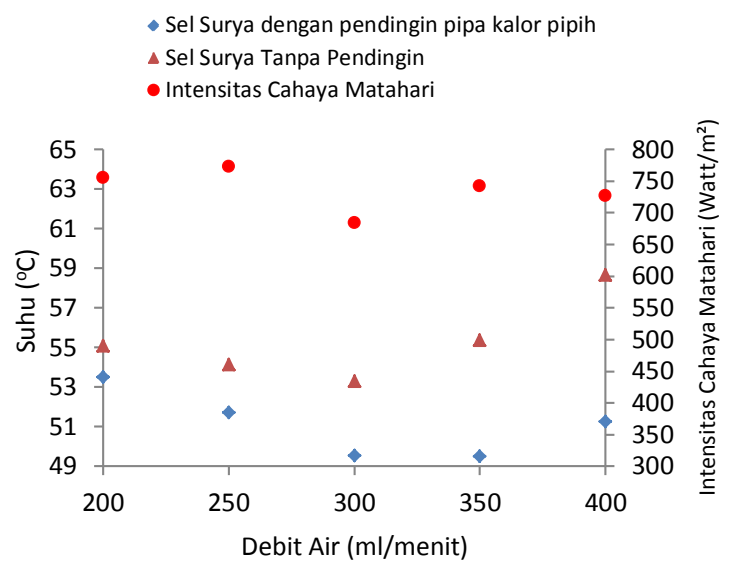

Figure 11. average surface temperature of the solar cell

• selisih suhu permukaan _ A Intensitas Cahaya Matahari

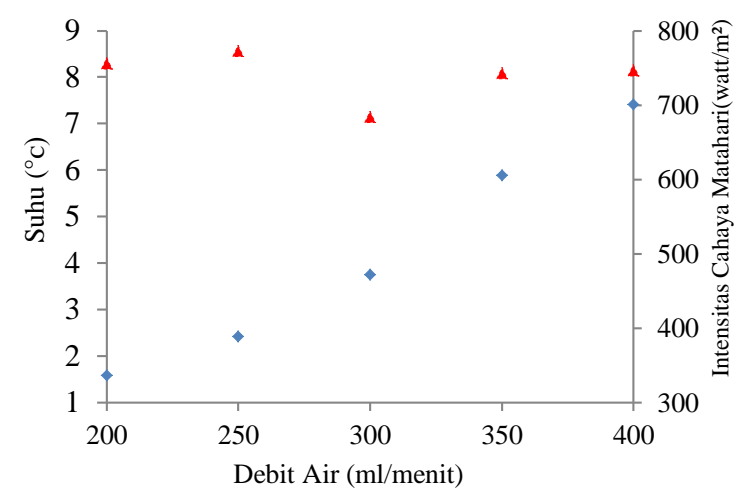

Figure 12. average difference surface temperature of the solar cell
- Sel Surya dengan pendingin pipa kalor pipih $\triangle$ Sel Surya Tanpa Pendingin

- Intensitas Cahaya Matahar

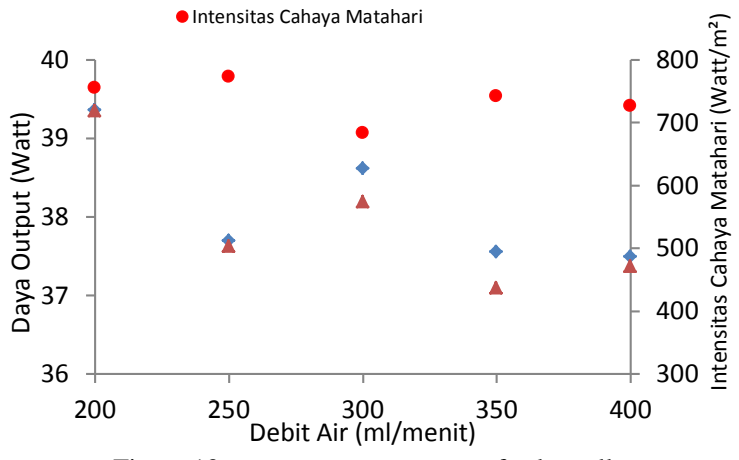

Figure 13. average power output of solar cells

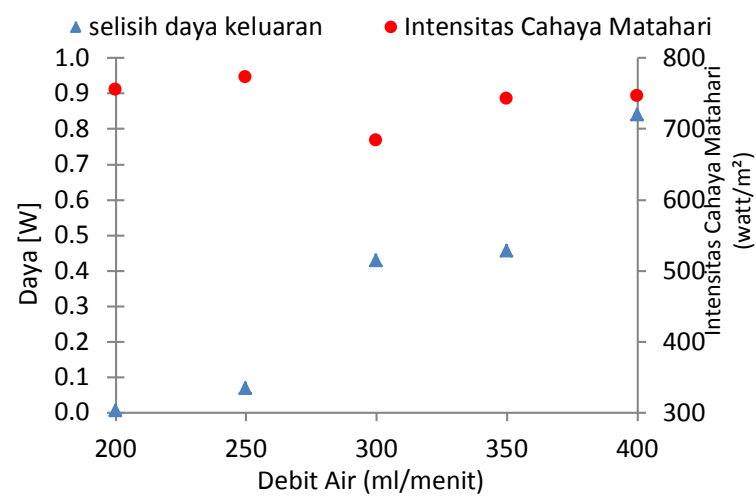

Figure 14. average difference power output of solar cells

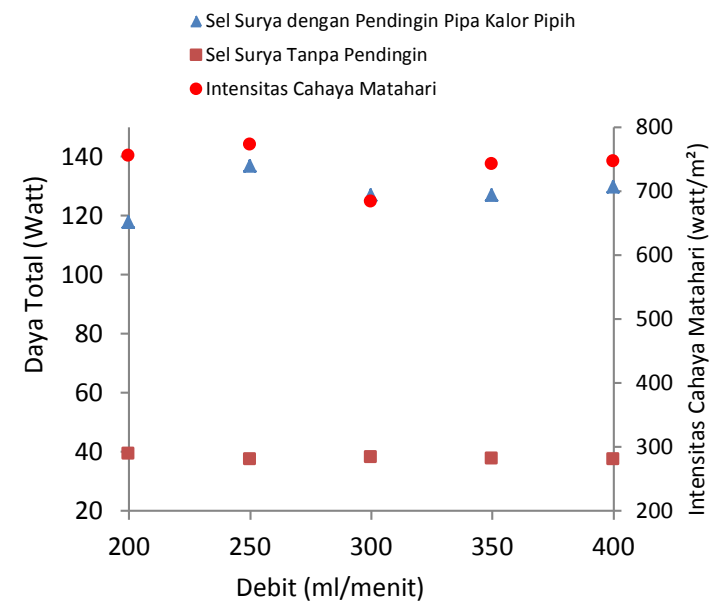

Figure 15. total output power of solar cell

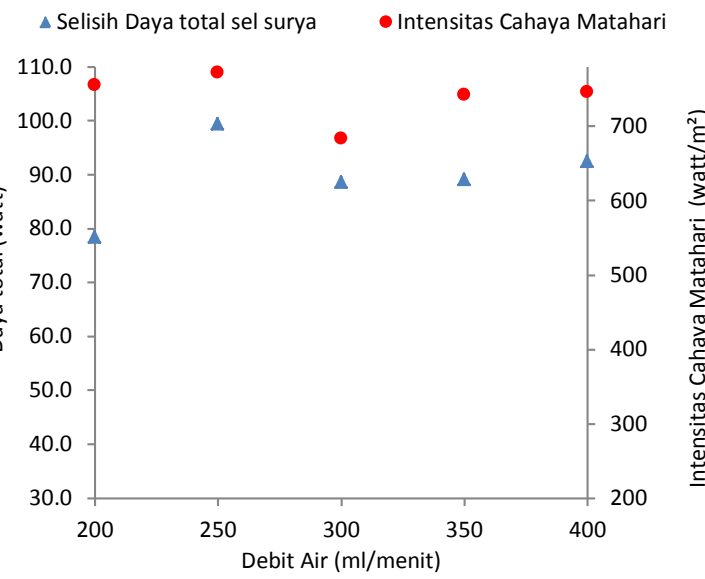

Figure 16. totaldifference of output power of solar cell 


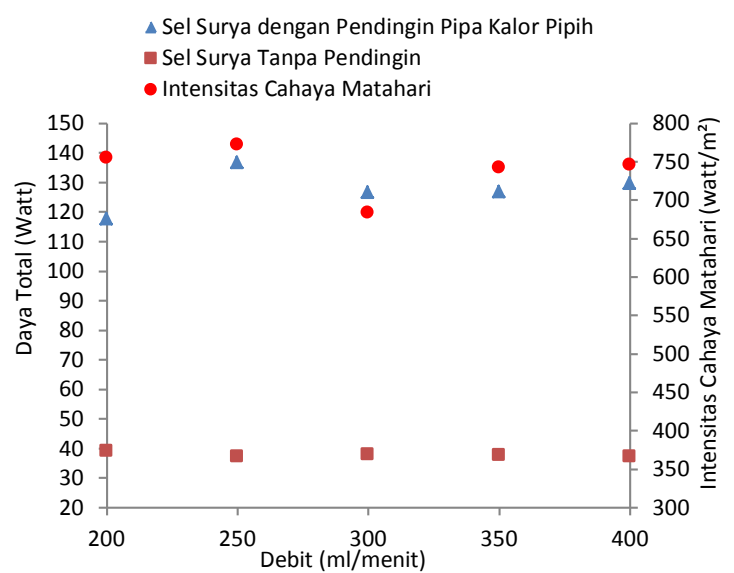

Figure 17. total efficiency of solar cell

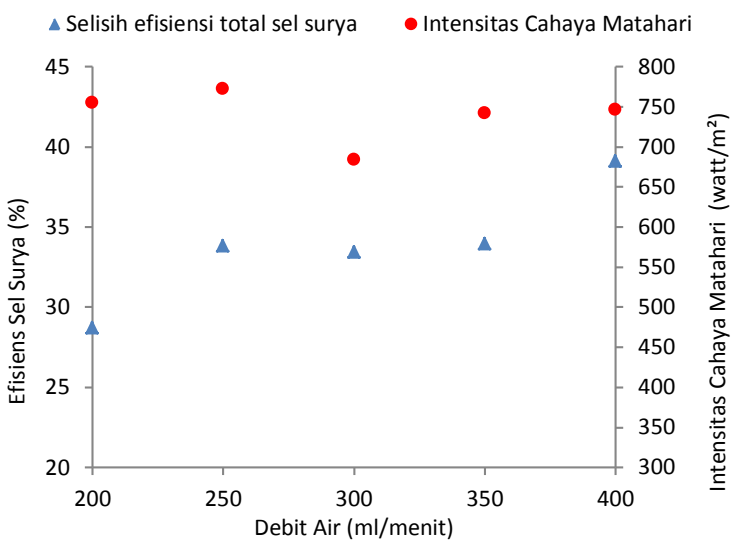

Figure 18. total difference of efficiency of solar cell

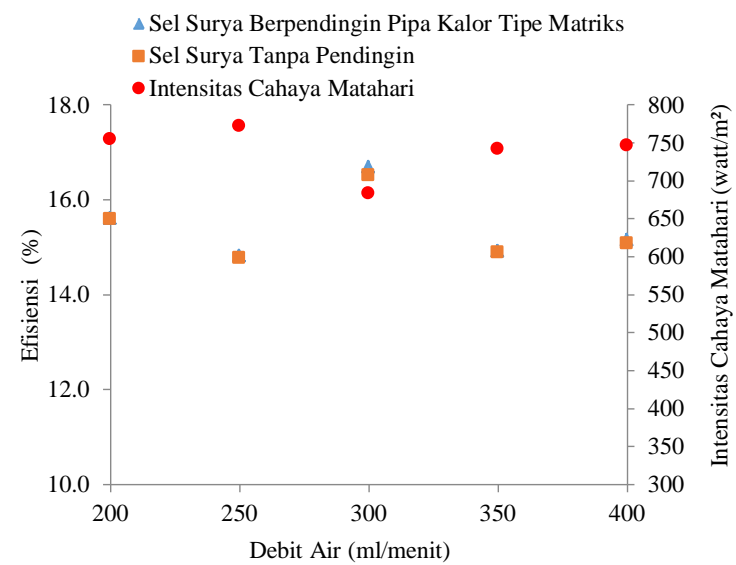

Figure 19. Average efficiency of solar cell

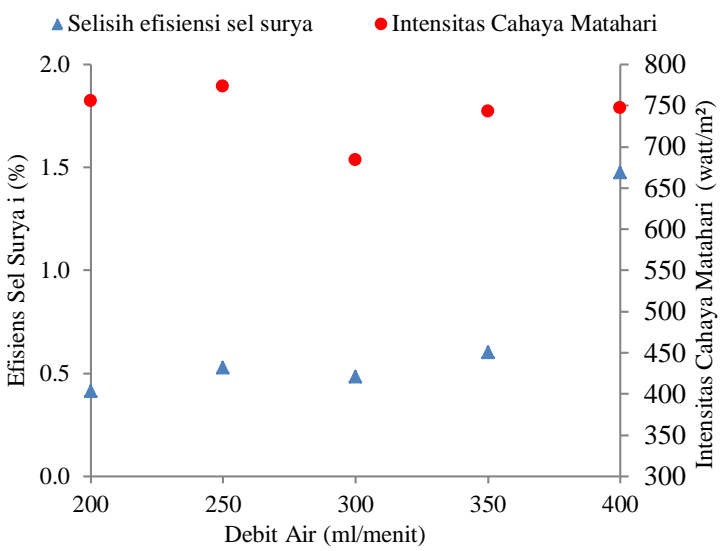

Figure 20. Average difference of efficiency of solar cell

TABLE 1.

RESULTS OF TESTING THE WORKING FLUID FILLING RATIO

\begin{tabular}{cccc}
\hline \hline No. & $\begin{array}{c}\text { Volume } \\
{[\mathbf{m l}]}\end{array}$ & $\begin{array}{c}\text { Filling } \\
\text { ratio [\%] }\end{array}$ & $\begin{array}{c}\text { Heat propagation } \\
\text { time (second) }\end{array}$ \\
\hline 1 & 30 & 7 & 18 \\
2 & 37 & 10 & 19 \\
3 & 45 & 13 & 23 \\
4 & 55 & 15 & 15 \\
5 & 74 & 20 & 9 \\
6 & 100 & 27 & 13 \\
7 & 111 & 30 & 12 \\
8 & 130 & 50 & 15 \\
\hline \hline
\end{tabular}

